Cumhuriyet University

Journal of Economics and Administrative Sciences

E-ISSN: 2687-4032

2021, 22(2), pp.378-393.

Doi: 10.37880/cumuiibf.984188

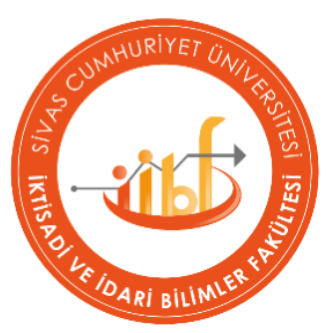

\title{
HOT AIR BALLOON RIDES IN CAPPADOCIA: A BUSINESS MODEL TO STIMULATE THE ECONOMY
}

\section{Eyup ATİOĞLU ${ }^{1}$}

\section{Abstract}

In this study, the effect of the number of tourists experiencing hot air balloon rides in Cappadocia on Turkey's international tourism income was examined using ARDL bounds test and Granger causality test. The dataset includes 60 observations on a monthly basis between 2015 and 2019. In the study, a cointegration relationship, which expresses a long-term balance between the number of tourists experiencing a hot air balloon ride in Cappadocia and Turkey's international tourism income, has been determined. According to the findings of the study, it has been determined that the number of tourists experiencing hot air balloon rides in Cappadocia has a significantly positive effect on Turkey's international tourism income in both the long and short term. In addition, according to the Granger causality test, a bidirectional causality relationship was determined between the number of tourists experiencing hot air balloon rides in Cappadocia and Turkey's international tourism income.
Article History:

Date submitted:

18 August 2021

Date accepted:

5 October 2021

\section{Jel Codes:}

C22, C58, L83

\section{Keywords:}

Hot Air Balloon Ride, International Tourism Income, $A R D L$

Approach, Granger Causality Test

Suggested Citation: Atioğlu, E. (2021). Hot Air Balloon Rides in Cappadocia: A Business Model to Stimulate the Economy. Cumhuriyet University Journal of Economics and Administrative Sciences, 22(2), 378-393.

${ }^{1}$ Asst. Prof. Dr., Kapadokya University, School of Applied Sciences, Department of Aviation Management, eyup.atioglu@kapadokya.edu.tr, ORCID ID: 0000-0001-9460-4822 


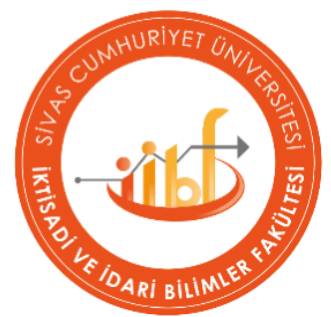

\section{KAPADOKYA'DA SICAK HAVA BALONU UÇUŞLARI: EKONOMIYİ CANLANDIRACAK BİR İS MODELI}

\section{Eyup ATIOOĞLU ${ }^{1}$}

\section{öz}

Bu çalışmada, Kapadokya'da sıcak hava balon turu deneyimi yaşayan turist sayısının Türkiye'nin uluslararası turizm gelirlerine etkisi ARDL sinır testi ve Granger nedensellik testi kullanılarak incelenmiştir. Veri seti, 2015-2019yılları arasında aylık bazda 60 gözlem içermektedir. Çalışmada, sıcak hava balonu uçuşlarına katılan turist sayısı ile Türkiye'nin uluslararası turizm gelirleri arasında uzun dönemli bir dengeyi ifade eden bir eşbütünleşme ilişkisi tespit edilmiştir. Çalışmanın bulgularına göre Kapadokya'da sıcak hava balon turu deneyimi yaşayan turist sayısının Türkiye'nin uluslararast turizm gelirleri üzerinde hem uzun hem de kisa vadede önemli ölçüde olumlu etkisinin olduğu saptanmıştır. Ayrıca Granger nedensellik testine göre Kapadokya'da sicak hava balon turuna katılan turist sayısı ile Türkiye'nin uluslararası turizm gelirleri arasında çift yönlü bir nedensellik ilişsisi tespit edilmiştir.
Makale Geçmişi:

Iletilen Tarih:

18 Ağustos 2021

Kabul Tarihi:

5 Ekim 2021

Jel Kodlarl:

C22, C58, L83

Anahtar Kelimeler:

Sicak Hava Balonu

Turu, Uluslararast

Turizm Geliri, ARDL

Yaklaşımı, Granger

Nedensellik Testi

Önerilen Alıntı: Atioğlu, E. (2021). Kapadokya'da Sıcak Hava Balonu Uçuşları: Ekonomiyi Canlandıracak Bir İş Modeli. Cumhuriyet Üniversitesi Iktisadi ve İdari Bilimler Dergisi, 22(2), 378-393.

${ }^{1}$ Dr. Öğretim Üyesi, Kapadokya Üniversitesi, Uygulamalı Bilimler Yüksekokulu, Havacılık Yönetimi Bölümü, eyup.atioglu@kapadokya.edu.tr, ORCID ID: 0000-0001-9460-4822 


\section{HOT AIR BALLOON RIDES IN CAPPADOCIA: A BUSINESS MODEL TO STIMULATE THE ECONOMY}

\section{INTRODUCTION}

Cappadocia is the world's one of the largest hot air balloon ride markets in terms of the number of flights, the number of tourists and the number of days suitable for meteorological flights, with its unique geological formations suitable for navigating with hot air balloons and its climate that allows an average of 250-270 days of flight per year. In Cappadocia, in 2021, 27 hot air balloon companies operate with 280 hot air balloons and serve around 500,000 tourists annually. Due to this successful business model, in recent years, many cities in Turkey have applied to the Turkish civil aviation authority in competition to host hot air balloon flights (SHGM, 2018) (Kapadokya Üniversitesi, 2021).

Cappadocia is one of the most popular tourism regions of Turkey with its nature and cultural tourism as well as hot air balloon rides. As a touristic product, the region attracts attention in both national and international tourism markets, as it has almost all the extraordinary requirements that today's post-modern tourists seek (Özen \& Güneren Özdemir, 2019).

Pomfret (2006) classified hot air balloon rides as air-based adventure tourism according to the traditional and contemporary adventure tourism classification. The fact that hot air balloons have only vertical control capability due to their design and nature and can navigate with the help of wind makes this touristic activity an adventurous one (Kapadokya Üniversitesi, 2021).

Adventure tourism, classified as hard and soft by Hill (1995), is defined as a special-purpose trip to explore a new experience in a natural environment or outdoor setting, often associated with personal challenge, involving perceived risk and controlled danger (Morrison \& O'Leary, 1996). Most activities in nature can involve adventure. Recreational activities involving adventure are also included in the scope of adventure tourism (Sung 2000: 21). Adventure tourism, as a niche tourism form, has attracted adventure-loving tourists in recent years (Swarbrooke, Beard, Leckie, \& Pomfret, 2003), and its meaning can show variations for different participant groups in terms of perceived risk (Shephard \& Evans, 2008). This perceived risk can also motivate the tourists participating in adventure tourism (Zuckerman, 1990).

Hot air balloon rides are one of the major adventure tourism options and are only conducted in places with an obstacle-free take-off and landing area and suitable meteorological conditions. Today, hot air balloon flights are offered to adventure-loving tourists in a variety of areas ranging from protected areas in Africa to coastal areas in Australia (Buckley, 2006).

Besides Cappadocia, the important places where hot air balloon rides are offered in the world are Albuquerque (the USA), Bagan (Myanmar), Serengeti (Tanzania), Loire Valley (France), Bristol (the UK), Istria (Croatia), Yarra Valley (Australia), Tuscany (Italy), Chateau-D’Òex (Switzerland), Mount Bromo (Indonesia), Vermont (the USA), Arctic Bay (Canada), Melbourne (Australia), Queenstown (New Zealand) (Sevim \& Güçer, 2019).

In the global tourism industry, post-modern tourists may have different desires such as experiencing soft or hard adventure activities. (Buckley, 2006). Since all adventure tourism activities have unique characteristics, the experience of tourists participating in adventure tourism varies. According to Pine and Gilmore (1999), uniformly designed and standardized products and services in tourism activities are no longer sufficient to make a difference and provide economic growth.

Countries aiming to generate more income from the global tourism market have realized the economic value of adventure tourism, which is one of the fastest growing areas of the tourism 
Eyup ATIOĞLLU, 2021 Cilt: 22, Sayl: 2, ss.378-393.

industry (UNWTO, 2014: 9-10). The global tourism industry, which has become more complex in parallel with the development of different types of tourism such as adventure tourism, is segmented in terms of positioning, increasing its economic contribution. (Williams \& Soutar, 2009). According to the Allied Market Research (2020) report, the economic size created by global adventure tourism is $\$ 112$ billion in 2020 and it is expected to reach a market value of $\$ 1.169$ billion by 2028 .

This study makes an important contribution to the literature in terms of examining the effect of hot air balloon rides on international tourism income in Cappadocia, where the world's one of the largest commercial hot air balloon ride markets. In this study, the direction and degree of the causal relationship between the number of tourists experiencing a hot air balloon ride in Cappadocia and Turkey's international tourism income has been revealed.

\section{LITERATURE REVIEW}

It has been observed in the literature that hot air balloon rides have not been examined using econometric analysis. However, there are various studies on the economic aspects of adventure tourism in general in the current financial literature.

Rodenburg (1980), Wanhill (2000), Marques and Cunha (2010) found in their studies that adventure tourism supports economic growth. Zurick (1992), in his study, which argues that the share of adventure tourism in the tourism industry is increasing, has proposed a model of adventure travel spatial connectivity that will connect Nepal's remote borders with the global tourism market in a way that contributes to economic growth. McKay (2013) examined the economic effects of adventure tourism, especially in developed countries, making a noticeable difference and acting as a catalyst for economic growth. Yetim (2017) determined that adventure tourism creates profitability and commercial opportunities due to its increasing market potential as well as its various benefits. Buckley $(2003,2006)$ revealed that adventure tourism has an important economic role in driving the volume of global purchases of sportswear, activewear and sports equipment. Cater (2006) found that adventure tourism contributes approximately $\$ 220$ billion annually to the US economy. Furthermore, the research reveals that tourists engaged in commercial adventurous activities primarily seek thrill and excitement, rather than demanding real risks. The study revealed that the adventure tourism operators with the highest financial return are those who can turn the excitement into the new tourism products while reducing real risk levels.

Most of the studies on the economic aspects of adventure tourism have examined wildlife watching. Duffus and Dearden (1993) examined the economic impact of whale watching in the Johnstone Strait by surveying the expenditures made by whale watching tourists. According to the findings of the study, it was determined that whale watchers participating in adventure tourism spend $\$ 400$ per trip, and whale watchers contribute $\$ 4$ million to the economy of Vancouver Island. Wilkie and Carpenter (1999) found that adventure tourism income from protected areas are significantly less when compared to the maintenance costs of the areas. Since the capacity of adventure tourism has not been adequately evaluated, it has been determined that the income obtained from here is only $30 \%$ of the maintenance costs of the protected areas. Archbald and Naughton-Treves (2001) found in their study that human-wildlife conflict hinders local support for national parks. According to the findings of the study, it has been determined that local attitudes towards conservation can be improved if the incomes from adventure tourism are directly channeled to residents of these areas. Adams and Infield (2003) examined income from adventure 


\section{HOT AIR BALLOON RIDES IN CAPPADOCIA: A BUSINESS MODEL TO STIMULATE THE ECONOMY}

tourism and operating costs of the park based on mountain gorilla watching in Uganda's Mgahinga National Park. In the study, it was determined that the capacity of the park could not be used effectively and financial difficulties were experienced due to the competition between different interest groups. It has also been found that the economic benefits of adventure tourism extend far beyond the visitor fees, including private sector investments such as hotels and tour buses. Parsons, Warburton, Woods-Ballard, Hughes, and Johnston (2003) applied a survey method to whale watching tourists in West Scotland during the tourism season of 2000. According to the findings of the study, it has been determined that about 242.000 tourists annually participate in cetaceanrelated tourism activities in Western Scotland, and the direct economic impact of the aforementioned adventure tourism is $£ 1.77$ million annually. In addition, in the study, it was determined that adventure tourism constitutes $2.5 \%$ of the total income obtained from tourism in the region, while adventure tourism in far coastal regions constitutes $12 \%$ of the total tourism income of the region. Barnes, Schier, and Van Rooy (1999) found that adventure tourism based on wildlife watching contributes significantly to Namibia's overall economy. Sekhar (2003) examined the relationship between whether local people support adventure tourism and the economic contributions from tourism. In the study, a positive relationship was determined between the benefits of the local people from adventure tourism and the support given to the protected areas, and it was determined that the economic benefits positively influenced people's attitudes towards protection. In the study, it has been revealed that the local people support the protection of the Sariska Tiger Reserve in India due to the economic contributions.

Various studies have also been conducted in the literature on the economic effects of adventure tourism, including physical activities. Bowker, English, and Donovan (1996) studied the travel cost method for guided whitewater rafting on the Chattooga River and the Nantahala River in North Carolina. Based on the findings of the study, it was found that the significant economic contribution is derived from adventure tourism, depending on the modeling assumptions and river quality. Fix and Loomis (1997) estimated the value of mountain biking as one of the adventure tourism types in their study. In the study, it was determined that with the travel cost model method, an annual income of about $\$ 8$ million was obtained from the track in Moab.

\section{DATA}

The data set of the present study included 60 observations on a monthly basis between 2015 and 2019. In the study, Turkey's international tourism income (InINCOME) was determined as the dependent variable, while the number of tourists experiencing a hot air balloon ride in Cappadocia $(\operatorname{lnPAX})$ was the independent variable.

The number of tourists experiencing a hot air balloon ride between 2015 and 2019 was obtained from the reports of the Cappadocia University Hot Air Balloon and Airship Application and Research Center and the Turkish Civil Aviation Authority, while information reagarding the international tourism income was obtained from the Turkish Statistical Institute database. In the study, the effect of the number of tourists experiencing a hot air balloon ride on Turkey's international tourism income has been determined. 
Eyup ATIOOĞLU, 2021 Cilt: 22, Sayl: 2, ss.378-393.

\section{METHODOLOGY AND EMPIRICAL RESULTS}

The high level of correlation between time series variables while establishing econometric models may be due to spurious regression (Holden \& Thomson, 1992). The cointegration tests developed by Engle \& Granger (1987) and Johansen \& Juselius (1990) are based on the stationarity of the series at the first difference.

However, the ARDL method gives valid results regardless of whether the series is level, first difference, or a combination of both. The point to be noted here is that the series should not be I(2) (Pesaran, Shin, \& Smith, 2001). The ARDL model is defined as follows to analyze the relationship between the number of tourists experiencing a hot air balloon ride $(\ln P A X)$ and Turkey's international tourism income (InINCOME).

$$
y_{t}=\alpha+\sum_{i=1}^{p} \gamma_{i} y_{t-i}+\sum_{j=1}^{k} \sum_{i=0}^{q_{j}} X_{j, t-i}{ }^{\prime} \beta_{j, i}+\epsilon_{t}
$$

In the model, $p$ is the lag number of the dependent variable, $\mathrm{q}_{1}$ is the lag number of the first explanatory variable, and $\mathrm{q}_{\mathrm{k}}$ is the lag number of the $\mathrm{k}_{\mathrm{th}}$ explanatory variable.

The stationarity of the time series is important during the application of econometric analysis. In order to obtain econometrically meaningful relationships, time series must be stationary (Gujarati, 2003, p. 797). If the model is built with non-stationary series, the spurious regression problem arises and significant relationships between the variables cannot be determined (Granger and Newhold, 1974). Accordingly, the Augmented Dickey-Fuller (ADF) unit root test was used to examine the stationarity levels of the series.

According to the ADF test given in Table 1, it was determined that the variables were stationary at different levels, but not I(2). The stationarity levels of the variables have an important role in determining the econometric model to be applied. In this context, ARDL approach was applied in the study because the variables are stationary at different levels.

Table 1: Augmented Dickey-Fuller Unit Root Test

\begin{tabular}{|l|l|c|c|}
\hline \multicolumn{2}{|c|}{ Variables } & Intercept & Intercept\&Trend \\
\hline InINCOME & $\mathrm{I}(1)$ & $-7.4559^{*}$ & $-8.2799^{*}$ \\
\hline $\operatorname{lnPAX}$ & $\mathrm{I}(0)$ & $-3.6419^{*}$ & $-3.9330^{*}$ \\
\hline
\end{tabular}

Not: * Statistically significant at the $5 \%$

As seen in Figure 1, the appropriate model was determined to be the ARDL $(4,3)$ model using the Akaike Information Criteria. 4 lags of Turkey's international tourism income (lnINCOME) and 3 lags of the number of tourists experiencing hot air balloon rides in Cappadocia (lnPAX) were included in the model. 


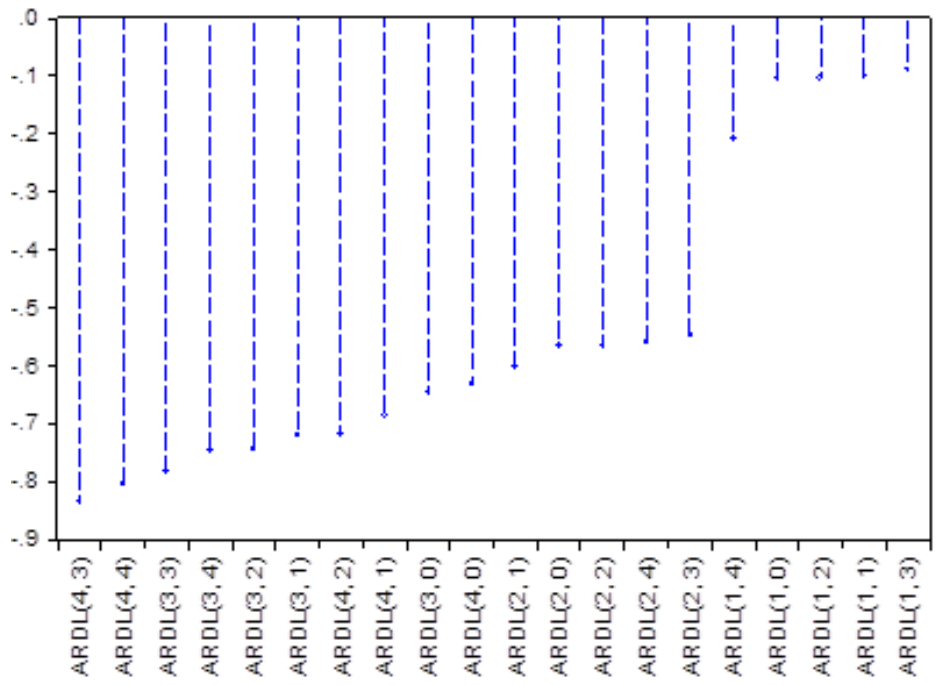

Figure 1: Akaike Information Criteria

The long-term cointegration relationship between the variables was analyzed with the ARDL bounds test. If a long-term relationship is detected between the variables, the long- and short-term coefficients should be estimated. In addition, the error correction term, which shows how long it will take to correct the short-term deviations in the estimated coefficients, is also evaluated according to the results of the analysis. Accordingly, the results of the bound test conducted to investigate the cointegration relationship between Turkey's international tourism income and the number of tourists experiencing balloon rides are given in Table 2.

Table 2: ARDL Bounds Test

\begin{tabular}{|c|c|c|}
\hline Test Statistic & Value & k \\
\hline F-statistic & 24.9207 & 1 \\
\hline Critical Value Bounds & \multicolumn{2}{|c|}{} \\
\hline Significance & I0 Bound & I1 Bound \\
\hline $10 \%$ & 4.04 & 4.78 \\
\hline $5 \%$ & 4.94 & 5.73 \\
\hline $2.5 \%$ & 5.77 & 6.68 \\
\hline $1 \%$ & 6.84 & 7.84 \\
\hline
\end{tabular}

The ARDL bounds test results, which were conducted to investigate the cointegration relationship between Turkey's international tourism income and the number of tourists participating 
in the hot air balloon ride, are given in Table 2. The upper critical value, the $\mathrm{F}$ statistical value (5.73), shows that there is a cointegration relationship between the variables at the 5\% significance level. The coefficient and direction of the long-term relationship between the variables are estimated in Table 3.

In the analysis, long run relationship was found between the number of tourists experiencing hot air balloon rides in Cappadocia and Turkey's international tourism income. Accordingly, $1 \%$ increase in the number of tourists experiencing hot air balloon rides in Cappadocia, while other factors being constant, increased Turkey's international tourism income by $0.42 \%$ in the long run. This empirical finding shows that the number of tourists experiencing hot air balloon rides in Cappadocia has a significantly positive effect on Turkey's international tourism income.

Table 3: Long Run Coefficient of Cointegration

\begin{tabular}{ccccc} 
Variable & Coefficient & Std. Error & t-Statistic & Prob. \\
\hline $\ln P A X$ & 0.4229 & 0.0647 & 6.5368 & 0.0000 \\
\hline C & 17.4821 & 0.6681 & 26.1656 & 0.0000 \\
\hline
\end{tabular}

The error correction model, which was established in order to provide information about the short-term balance between the variables in the ARDL model after the estimation of the long-term coefficients, expresses the situation in which the short-term imbalances are eliminated in the longterm. The coefficient of error correction term in the model is presented in Table 4.

Table 4: Error Correction Model

\begin{tabular}{|c|c|r|r|r|}
\hline Variable & Coefficient & Std. Error & \multicolumn{1}{|c|}{ t-Statistic } & \multicolumn{1}{|c|}{ Prob. } \\
\hline D(LNINCOME(-1)) & 0.737237 & 0.118553 & 6.218624 & 0.0000 \\
\hline D(LNINCOME(-2)) & 0.611247 & 0.147647 & 4.139922 & 0.0001 \\
\hline D(LNINCOME(-3)) & 0.350167 & 0.167785 & 2.087004 & 0.0423 \\
\hline D(LNYOLCU) & 0.030349 & 0.092078 & 0.329600 & 0.7432 \\
\hline D(LNYOLCU(-1)) & -0.048843 & 0.098793 & -0.494397 & 0.6233 \\
\hline D(LNYOLCU(-2)) & -0.244166 & 0.087552 & -2.788825 & 0.0076 \\
\hline CointEq(-1) & -0.905996 & 0.134347 & -6.743678 & 0.0000 \\
\hline
\end{tabular}


The significance and direction of the error correction term are taken into account when evaluating the error correction model. If the error correction term is statistically significant and negative, this indicates that the error correction model works and the short-term imbalances are eliminated in the long-term.

According to the findings of the model, the coefficient of the lagged $\mathrm{ECM}_{\mathrm{t}-1}$ is negative and statistically significant. The coefficient of the ECM indicates the rate of return and adjustment to the long-run equilibrium after a short-term shock. According to the results of the analysis, the error correction coefficient was determined as $-0,90$. Accordingly, when Turkey's international tourism income deviates from its long-term balance, it is estimated that $90 \%$ of the deviation will disappear in the next period and international tourism income will return to its long-term balance. In other words, it has been determined that the deviation from the long-term balance will correct itself after about 1 month. This value indicates a fairly rapid adjustment.

The findings of the tests performed to check whether there is any heteroskedasticity in the model and to investigate autocorrelation problems in the model results are given in Table 5. According to the results, no heteroskedasticity and autocorrelation problems were detected in the model, and it was determined that the series had a normal distribution.

Table 5: Diagnostic Tests

\begin{tabular}{|l|l|l|l|}
\hline \multicolumn{4}{|l|}{ Breusch-Godfrey Serial Correlation LM Test } \\
\hline F-statistic & 1.1927 & Prob. F(1,46) & 0.2805 \\
\hline Obs*R-squared & 1.4153 & $\begin{array}{l}\text { Prob. Chi- } \\
\text { Square(1) }\end{array}$ & 0.2342 \\
\hline Heteroskedasticity & Test: Breusch-Pagan-Godfrey & 0.0758 \\
\hline F-statistic & 1.9410 & Prob. F(8,47) & 0.0842 \\
\hline Obs*R-squared & 13.9068 & $\begin{array}{l}\text { Prob. Chi- } \\
\text { Square(8) }\end{array}$ & 0,5937 \\
\hline Jarque-Bera & 1,0426 & Prob. & \\
\hline
\end{tabular}

In order to examine the stability of the parameters after the ARDL Bounds Test approach, whether the ARDL model contained any structural break was examined with the CUSUM and CUSUMQ structural break tests developed by Brown, Durbin and Evans (1975). If the curves obtained from the CUSUM and CUSUMQ test statistics for error terms are between the critical limit of 5\% significance, the estimated coefficients are considered to be stable in the long run. The CUSUM and CUSUMQ test results for the model are given in Figure 2. 
Eyup ATİŎLU, 2021 Cilt: 22, Sayı: 2, ss.378-393.
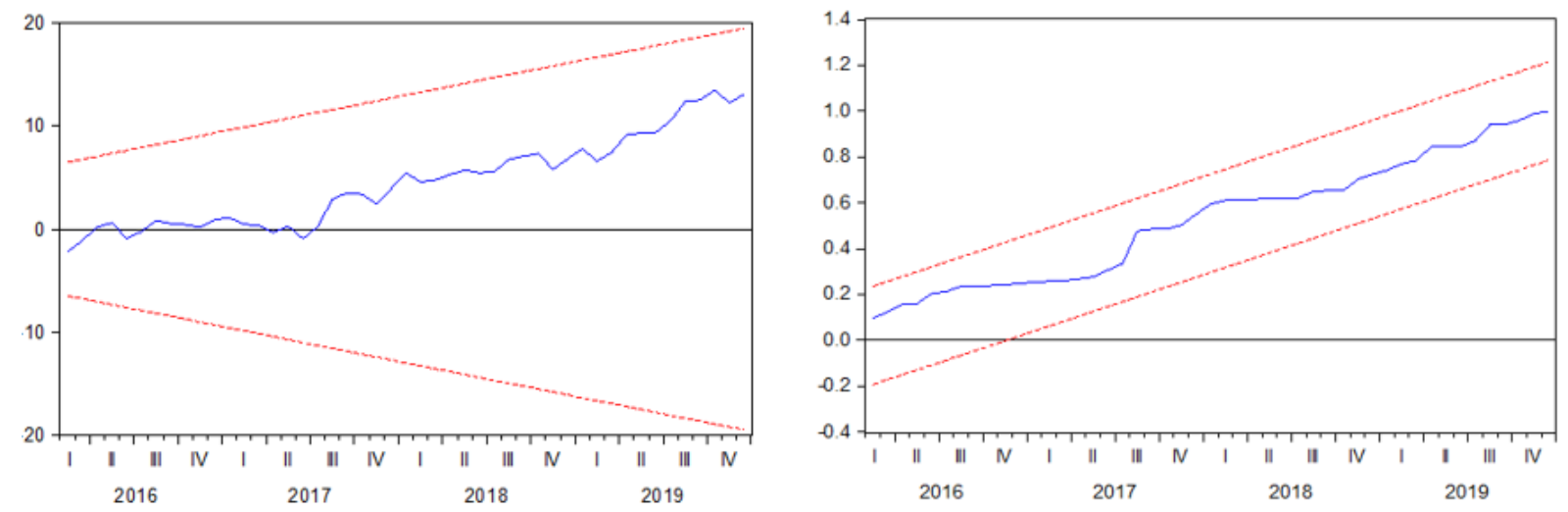

Figure 2: Plot of CUSUM (left panel) and CUSUMQ (right panel).

Since the curves obtained from the CUSUM and CUSUMQ test statistics in the study were between the critical limits, it has been determined that the coefficient of the independent variable is stationary in the long run and there is no structural break.

Table 6: Granger Causality Test

\begin{tabular}{|ll|c|c|}
\hline \multicolumn{2}{|c|}{$\mathrm{H}_{0}$} & F-statistic & Prob. \\
\hline $\ln \mathrm{PAX} \rightarrow \operatorname{lnINCOME}$ & 4.65861 & 0.0137 \\
\hline $\ln \mathrm{NNCOME} \rightarrow \operatorname{lnPAX}$ & 16.2172 & $3 . \mathrm{E}-06$ \\
\hline
\end{tabular}

In Table 6, the existence of a causal relationship between the variables was investigated. As seen in the table, a bidirectional causality relationship has been determined between the number of tourists experiencing hot air balloon rides in Cappadocia and Turkey's international tourism incomes. In addition, this result supports the long-term coefficient results in the ARDL model. It has been determined that the findings are in parallel with the literature in terms of the economic effects of adventure tourism (Rodenburg, 1980; Wanhill, 2000; Marques and Cunha, 2010; McKay, 2013; Cater, 2006; Duffus and Dearden, 1993). 


\section{CONCLUSIONS}

In the present study, the relationship between the number of tourists experiencing a hot air balloon ride and international tourism income was examined.

According to the coefficients calculated with ARDL-ECM models, the number of tourists experiencing hot air balloon rides in Cappadocia has a significantly positive effect on Turkey's international tourism income in both the long and short terms. According to the findings of the study, while other factors are constant, $1 \%$ increase in the number of tourists experiencing hot air balloon rides in Cappadocia increases Turkey's international tourism incomes by $0.42 \%$ in the long run. In addition, according to the Granger causality test, a bidirectional causality relationship was determined between the number of tourists experiencing hot air balloon rides in Cappadocia and Turkey's international tourism incomes.

The tourism sector, which is becoming increasingly important due to the benefits it provides and its role as a commercial activity that creates demand and growth for many sectors, is an important tool in creating income, employment and tax revenues, and alleviating balance of payments problems.

The hot air balloon ride industry in Cappadocia continues to grow. The safe and sustainable growth of the hot air balloon ride industry, both in Cappadocia and in other cities suitable for hot air balloon ride, should be encouraged due to its contribution to international tourism income.

According to the findings obtained in the study, it is expected that hot air balloon ride, as an important business model, will support the recovery of Turkey's international tourism incomes after COVID-19 period, which caused a dramatic decrease in tourism income. 
Eyup ATíŏ́LU, 2021 Cilt: 22, Sayl: 2, ss.378-393.

\section{REFERENCES}

Adams, W. M., \& Infield, M. (2003). Who is on the Gorilla's Payroll? Claims on Tourist Revenue from a Ugandan National Park. World development, 31(1), 177-190. https://doi.org/10.1016/S0305-750X(02)00149-3.

Allied Market Research, (2021, 23 April). Adventure Tourism Market. https://www.alliedmarketresearch.com/adventure-tourism-market.

Archabald, K., \& Naughton-Treves, L. (2001). Tourism Revenue-Sharing Around National Parks in Western Uganda: Early Effort to Identify and Reward Local Communities. Environmental conservation, 28(2), 135-149. https://doi.org/10.1017/S0376892901000145.

Barnes, J. I., Schier, C., \& Van Rooy, G. (1999). Tourists' Willingness to Pay for Wildlife Viewing and Wildlife Conservation in Namibia. South African Journal of Wildlife Research-24Month Delayed Open Access, 29(4), 101-111. Doi: 10.10520/EJC117083

Bowker, J. M., English, D. B., \& Donovan, J. A. (1996). Toward A Value for Guided Rafting on Southern Rivers. Journal of Agricultural and Applied Economics, 28(2), 423-432. https://doi.org/10.1017/S1074070800007410.

Brown, R.L., Durbin, J. \& Evans, J.M. (1975). Techniques for Testing the Constancy of Regression Relationships Over Time. Journal of the Royal Statistical Society: Series B (Methodological), 37(2), 149-163. https://doi.org/10.1111/j.2517-6161.1975.tb01532.x.

Buckley R. (2003). Adventure Tourism and The Clothing, Fashion and Entertainment Industries. Journal of Ecotourism, 2(2), 126-134. https://doi.org/10.1080/14724040308668139.

Buckley R. (2006). Adventure Tourism. CAB International

Cater C, I, (2006). Playing With Risk? Participant Perceptions of Risk and Management Implications in Adventure Tourism. Tourism Management, 27(2), 317-325. https://doi.org/10.1016/j.tourman.2004.10.005.

Duffus, D. A., \& Dearden, P. (1993). Recreational Use, Valuation, and Management, of Killer Whales (Orcinus Orca) on Canada's Pacific Coast. Environmental Conservation, 20(2), 149-156. https://doi.org/10.1017/S0376892900037656.

Engle R.F. \& Granger C.W. J. (1987). Co-Integration and Error Correction: Representation, Estimation and Testing. Econometrica, 55, 251-276. https://doi.org/10.2307/1913236.

Fix, P., \& Loomis, J. (1997). The Economic Benefits of Mountain Biking at One of Its Meccas: An Application of The Travel Cost Method to Mountain Biking in Moab, Utah. Journal of Leisure Research, 29(3), 342-352. https://doi.org/10.1080/00222216.1997.11949800.

Granger, C. W., \& Newbold, P. (1974). Spurious Regressions in Econometrics. Journal of Econometrics, 2(2), 111-120. Doi: 10.1016/0304-4076(74)90034-7

Gujarati, D.N. (2003). Basic econometrics (4. Edition). McGraw-Hill.

Hill, B. J. (1995). A Guide to Adventure Travel. Parks \& Recreation (Arlington), 30(9), 56-65. Doi: 19961802162

Johansen, S. (1988). Statistical Analysis of Cointegration Vectors. Journal of Economic Dynamics and Control, 12, 231-254. https://doi.org/10.1016/0165-1889(88)90041-3. 


\section{HOT AIR BALLOON RIDES IN CAPPADOCIA: A BUSINESS MODEL TO STIMULATE THE ECONOMY}

Johansen, S. (1989). Estimation and Hypothesis Testing of Cointegration Vectors in Gaussian Vector Autoregressive Models. Institute of Mathematical Statistics, University of Copenhagen, 1-52. https://doi.org/10.1016/0165-1889(88)90041-3.

Johansen, S. and Juselius K. (1990). Maximum Likelihood Estimation and Inference on Cointegration with Applications to The Demand for Money. Oxford Bulletin of Economics and Statistics, 52 (2), 169- 210.

Kapadokya Üniversitesi, (2021, 5 May). Balon Uçuş Sahasında Zipline Projesine İlişkin Emniyet Risklerinin Değerlendirilmesi, https://hotairballoon.kapadokya.edu.tr/raporlar-veanalizler/kapadokya-balon-ucus-sahasinda-zipline-projesine-iliskin-emniyet-risklerinindegerlendirilmesi.

Marques L. \& Cunha C. (2010). Literary Rural Tourism Enterprise: Case Study Evidence from Northern Portugal. Presentation at the ATLAS conference, Limassol, Cyprus, 3-5 November 2010. https://doi.org/10.1080/19407963.2013.801158.

McKay, T. (2013). Adventure Tourism: Opportunities and Management Challenges for SADC Destinations. Acta Academica, 45(3), 30-62. Doi: 10520/EJC144233.

Özen, İ. A., \& Özdemir, E. G. (2019). Kapadokya Sicak Hava Balonculuğu Üzerine Nitel Bir Araştırma, Nevşehir Hacı Bektaş Veli Üniversitesi SBE Dergisi, 9(2), 579-595. Doi: $51363 / 591558$

Parsons, E. C. M., Warburton, C. A., Woods-Ballard, A., Hughes, A., \& Johnston, P. (2003). The Value of Conserving Whales: The Impacts of Cetacean-Related Tourism on The Economy of Rural West Scotland. Aquatic Conservation: Marine and Freshwater Ecosystems, 13(5), 397-415. https://doi.org/10.1002/aqc.582.

Pesaran H., Shin Y. \& Smith R. J. (2001). Bound Testing Approaches to The Analysis of Long Run Relationship. Journal of Applied Econometrics, 16(3), 289-326. https://doi.org/10.1002/jae.616.

Pine, B. Joseph; Gilmore, James H. (1999). The Experience Economy. Harvard Business Review Press

Pomfret, G. (2006). Mountaineering Adventure Tourists: A Conceptual Framework for Research. Tourism Management, 27(1), 113-123. https://doi.org/10.1016/j.tourman.2004.08.003.

Rodenburg E. (1980). The Effect of Scale in Economic Development: Tourists in Bali. Annals of Tourism Research, 7(2), 177-196. https://doi.org/10.1016/0160-7383(80)90003-1.

Sekhar, N. U. (2003). Local People's Attitudes Towards Conservation and Wildlife Tourism Around Sariska Tiger Reserve, India. Journal of Environmental Management, 69(4), 339347. https://doi.org/10.1016/j.jenvman.2003.09.002.

Kül, S., \& Güçer, E. (2019). Determining the Leisure Satisfaction Levels of Individuals Having Hot Air Balloon Ride as An Adventurous Recreational Activity. Journal of Multidisciplinary Academic Tourism, 4(2), 63-69. https://doi.org/10.31822/jomat.618715.

Shephard, G., \& Evans, S. (2005). Adventure Tourism - Hard Decisions, Soft Options and Home For Tea: Adventure on The Hoof. in M. Novelli (Ed.), Niche tourism: Contemporary Issues, Trends and Cases, 201-209. Doi: 10.1016/B978-0-7506-6133-1.50026-3 
Eyup ATİOĞLU, 2021 Cilt: 22, Sayl: 2, ss.378-393.

SHGM, (2021, 5 May). SHGM'den Turizme Önemli Katkı: Balon Faaliyetlerinde Yeni Noktalar, http://web.shgm.gov.tr/tr/haberler/5874-shgm.

Sung, H. H. (2000). An Analysis of the Adventure Travel Market: From Conceptual Development to Market Segmentation [PhD]. Purdue University.

Sung, H. H., Morrison, A. M., \& O'Leary, J. T. (1996). Definition of Adventure Travel: Conceptual Framework for Empirical Application from The Providers' Perspective. Asia Pacific Journal of Tourism Research, 1(2), 47-67. https://doi.org/10.1080/10941669708721975.

Swarbrooke, J., Beard, C., Leckie, S., \& Pomfret, G. (2003). Adventure Tourism: the New Frontier. Butterworth-Heinemann.

UNWTO, (2021, 1 April). Global Report on Adventure Tourism. https://www.eunwto.org/doi/epdf/10.18111/9789284416622.

Wanhill S. (2000). Small and Medium Tourism Enterprises. Annals of Tourism Research, 27(1), 132-147. https://doi.org/10.1016/S0160-7383(99)00072-9.

Wilkie, D. S., \& Carpenter, J. F. (1999). Can nature tourism help finance protected areas in the Congo Basin?. Oryx, 33(4), 332-338. https://doi.org/10.1046/j.1365-3008.1999.00080.x.

Williams P \& G N Soutar, (2009). Value, Satisfaction and Behavioural Intentions in An Adventure Tourism Context. Annals of Tourism Research 36(3): 413-438. https://doi.org/10.1016/j.annals.2009.02.002.

Yetim, A. C. (2017). Determining the Benefits of Adventure Tourism from A Providers' Perspective in Fethiye. Global Journal of Business, Economics and Management: Current Issues, 7(1), 2-7.

Zuckerman, M. (1990). The Psychophysiology of Sensation Seeking. Journal of Personality, 58(1), 313-345. https://doi.org/10.1037/11555-000.

Zurick, D. N. (1992). Adventure Travel and Sustainable Tourism in the Peripheral Economy of Nepal. Annals of the Association of American Geographers, 82(4), 608-628. https://doi.org/10.1111/j.1467-8306.1992.tb01720.x. 


\section{HOT AIR BALLOON RIDES IN CAPPADOCIA: A BUSINESS MODEL TO STIMULATE THE ECONOMY}

\section{EXTENDED ABSTRACT}

Cappadocia is the world's one of the largest hot air balloon ride markets in terms of the number of flights, the number of tourists and the number of days suitable for meteorological flights, with its unique geological formations suitable for navigating with hot air balloons and its climate that allows an average of 250-270 days of flight per year. In Cappadocia, in 2021, 27 hot air balloon companies operate with 280 hot air balloons and serve around 500,000 tourists annually. Due to this successful business model, in recent years, many cities in Turkey have applied to the Turkish civil aviation authority in competition to host hot air balloon flights (SHGM, 2018) (Kapadokya Üniversitesi, 2021).

Cappadocia is one of the most popular tourism regions of Turkey with its nature and cultural tourism as well as hot air balloon rides. As a touristic product, the region attracts attention in both national and international tourism markets, as it has almost all the extraordinary requirements that today's post-modern tourists seek (Özen \& Güneren Özdemir, 2019).

Pomfret (2006) classified hot air balloon rides as air-based adventure tourism according to the traditional and contemporary adventure tourism classification. The fact that hot air balloons have only vertical control capability due to their design and nature and can navigate with the help of wind makes this touristic activity an adventurous one (Kapadokya Üniversitesi, 2021). Adventure tourism, classified as hard and soft by Hill (1995), is defined as a special-purpose trip to explore a new experience in a natural environment or outdoor setting, often associated with personal challenge, involving perceived risk and controlled danger (Morrison \& O'Leary, 1996). Most activities in nature can involve adventure. Recreational activities involving adventure are also included in the scope of adventure tourism (Sung 2000: 21). Adventure tourism, as a niche tourism form, has attracted adventure-loving tourists in recent years (Swarbrooke, Beard, Leckie, \& Pomfret, 2003), and it can have different implications for different participant groups in terms of perceived risk (Shephard \& Evans, 2008). This perceived risk also motivates the tourists participating in adventure tourism (Zuckerman, 1990).

Countries aiming to generate more income from the global tourism market have realized the economic value of adventure tourism, which is one of the fastest growing areas of the tourism industry (UNWTO, 2014: 9-10). The global tourism industry, which has become more complex in parallel with the development of different types of tourism such as adventure tourism, is segmented in terms of positioning, increasing its economic contribution. (Williams \& Soutar, 2009). According to the Allied Market Research (2020) report, the economic size created by global adventure tourism is $\$ 112$ billion in 2020 and it is expected to reach a market value of $\$ 1.169$ billion by 2028 .

The present study makes an important contribution to the literature in terms of examining the effect of hot air balloon rides on international tourism income in Cappadocia, which is home to the world's one of the largest commercial hot air balloon ride markets. In this study, the direction and degree of the causal relationship between the number of tourists experiencing a hot air balloon ride in Cappadocia and Turkey's international tourism income has been revealed.

In this study, the effect of the number of tourists experiencing hot air balloon rides in Cappadocia on Turkey's international tourism incomes was examined using ARDL bounds test and Granger causality test. The data set of this study includes 60 observations on a monthly basis between 2015 and 2019. In the study, Turkey's international tourism income (InINCOME) was 
determined as the dependent variable, while the number of tourists experiencing a hot air balloon ride in Cappadocia (lnPAX) was the independent variable.

A cointegration relationship was determined as a result of the ARDL bounds test conducted to investigate the cointegration relationship between Turkey's international tourism income and the number of tourists experiencing hot air balloon rides. In this context, the coefficient and direction of the long-term relationship between the variables have been estimated, and $1 \%$ increase in the number of tourists experiencing hot air balloon rides increases Turkey's international tourism income by $0.42 \%$ in the long run, other factors being constant. This empirical finding shows that the number of tourists experiencing hot air balloon rides has a significantly positive effect on Turkey's international tourism income. There is no structural break in the long-term coefficient estimated according to the CUSUM and CUSUMQ tests. According to the findings of the model, the coefficient of the lagged $\mathrm{ECM}_{\mathrm{t}-1}$ is negative and statistically significant. The coefficient of the ECM indicates the rate of return and adjustment to the long-run equilibrium after a short-term shock. According to the results of the analysis, the error correction coefficient was determined as $-0,90$. Accordingly, when Turkey's international tourism income deviates from its long-term balance, it is estimated that $90 \%$ of the deviation will disappear in the next period and international tourism income will move back to their long-term balance. In other words, it has been determined that the deviation from the long-term balance will correct itself after about 1 month. This value indicates a fairly rapid adjustment.

Finally, the existence of a causal relationship between the variables was investigated and a bidirectional causality relationship was found between the number of tourists experiencing hot air balloon rides and Turkey's international tourism incomes. It has been determined that the findings are in parallel with the literature in terms of the economic effects of adventure tourism (Rodenburg, 1980; Wanhill, 2000; Marques and Cunha, 2010; McKay, 2013; Cater, 2006; Duffus and Dearden, 1993).

The tourism sector, which is becoming increasingly important due to the benefits it provides and its role as a commercial activity that creates demand and growth for many sectors, is an important tool in creating income, employment and tax revenues, and alleviating balance of payments problems. The hot air balloon ride industry in Cappadocia continues to grow. The safe and sustainable growth of the hot air ballooning industry, both in Cappadocia and in other cities suitable for hot air ballooning, should be encouraged due to its contribution to international tourism income.

According to the findings obtained in the study, it is expected that hot air balloon ride, as an important business model, will support the recovery of Turkey's international tourism income after COVID-19 period, which caused a dramatic decrease in tourism income. 